\title{
Immunohistochemical characterization of urothelial carcinoma
}

\author{
Rajcani $\mathrm{J}^{1}$, Kajo $\mathrm{K}^{2}$, Adamkov $\mathrm{M}^{3}$, Moravekova ${ }^{1}$, Lauko $\mathrm{L}^{1}$, Felcanova $\mathrm{D}^{1}$, Bencat $\mathrm{M}^{1}$
}

Alpha medical, a.s., Martin, Slovakia.rajcani.julius@alphamedical.sk

\begin{abstract}
From the archive of BB Biocyt company, 32 urinary bladder carcinomas (urothelium carcinomas, UC) and 7 cases of chronic cystitis were selected and examined in semiserial sections for the following antigens: 1) cell proliferation marker Ki-67 (expressed in the nuclei), 2) cell cycle regulator p16/INK4a polypeptide (expressed in the cytoplasm and nuclei), 3) urothelium marker p63 (expressed in the nuclei), 4) cytokeratin 7 (CK7). 5) cytokeratin 20 (CK20) and 6) high molecular weight cytokeratin (HMWCK). Invasive urothelium carcinomas showing a high grade dysplasia (invasive HG UC) comprised over the half (20 out of 32 ) of the investigated tumours. Microinvasion to lamina propria (seen in three HG papillary carcinomas) was regarded as an early infiltration even when the position of muscular layer could not be determined. Classical invasion across the urinary bladder wall and/or to surrounding tissues was found in 17 cases of low-differentiated HG UCs. The rest (9 out of 32 neoplasms) were either non-invasive papillary carcinomas of high (non-invasive HG UC, 5 cases) or low malignant potential (noninvasive LG UC, 4 cases). Finally, 3 cases were papillary urothelium neoplasms of low malignant potential (PUNLMP). HMWCK was present in all invasive tumours, whereas the frequency of other urothelium markers ranged from 65 to $88 \%$. Nevertheless, at least two markers were expressed in each invasive tumour. Staining for Ki-67 antigen was positive in over $50 \%$ of the nuclei of HG UCs, while in the LG UCs, the frequency of positive Ki-67 staining did not exceed $25 \%$. In PUNLMP, the positive rate of Ki-67 stained dysplastic cells was below $10 \%$. The staining for p16 antigen did not correlate with the degree of dysplasia within urothelium tumours. For routine diagnostic, we recommend to combine the Ki-67 staining with detection of HMWCK. In cases of chronic cystitis, which developed urothelial hyperplasia and/or squamous metaplasia, the presence of p63 antigen was a relevant marker confirming the urothelial origin of the altered transitional cells (Tab. 6, Fig. 4, Ref. 69). Full Text in PDF www.elis.sk.

Key words: urothelium carcinoma (UC), low grade (LG) dysplasia, high grade (HG) dysplasia, invasive growth, $\mathrm{Ki}-67, \mathrm{p} 16$ and p63 antigens, cytokeratin 7, cytokeratin 20, high molecular weight cytokeratin ( HMWCK).
\end{abstract}

During last years, the classification of urothelium carcinomas (UC) has undergone several improvements (43). The division into the non-invasive grade 1 (G1) neoplasms showing a low grade dysplasia, non-invasive papillary carcinomas of a high grade dysplasia (G2) and invasive low-differentiated carcinomas (G3) was revised. The G1 neoplasms were grouped to benign papillomas and papillary UCs of low malignant potential (LG UC). The distinction between papillary urothelium neoplasms of low malignant potential designated PUNLMP (19) as compared to papillary carcinomas of low malignant potential (LG UC) was highlighted by WHO classification (1998) and finally accepted the by International Society of Urology Pathologists (ISUP) in $2004(17,56)$. The difference between PUNLMP, LG UC and papillary carcinomas of high malignant potential (HG UC) was based on the symmetrical versus variable thickness of papillary structures and on cytological criteria reflecting the degree of the urothelium dysplasia (Tab. 1). These

${ }^{1}$ Alpha medical, a.s., Martin, Slovakia, ${ }^{2}$ BB BIOCYT, s.r.o., Banska Bys-
trica, and ${ }^{3}$ Institute of Histology, Jessenius Medical Faculty, Comenius
University Bratislava, Martin, Slovakia

Address for correspondence: J. Rajcani, MD, DSc, Alpha medical, a.s., Martin, Cervenej armady 25, SK-036 01 Martin, Slovakia. Phone: +421.905419262

Acknowledgement: The authors thank do Mrs. S. Drahosova for her excellent assistance. criteria of dysplasia have been more precisely defined (41, 42, $46,68)$, since PUNLMP should be distinguished from LG UC on one hand, as well as from urothelium hyperplasia on other hand.

PUNLMP as well as LG UC may appear as papillary tumours showing exophytic growth confined to the urothelial epithelium without disrupting its basement membrane (clinically pTa). A classical criterion for invasive growth is the infiltration of lamina muscularis $(1,2)$ of urinary bladder wall, typically found by pT2 tumours (18). In contrast, the pT1 tumours invade the connective tissue just adjacent to the basement membrane (i.e. the lamina propria), but does not grow into the smooth muscle layer. At histological examination, the pT1 tumours are mainly non-invasive (and/or microinvasive) papillary carcinomas of high malignant potential (HG UCs). The most progressed UCs grow not only across the urinary bladder wall, but also into surrounding adipose tissue (pT3) and/or to neighbour organs including regional lymph nodes (pT4). In men, prostata gland is most frequently involved. At histological examination, the invasive HG UCs (former G3) correspond mainly to non-differentiated UCs consisting of pleomorphic and/or anaplastic cells.

As mentioned, the pT1 tumours are high grade (HG) papillary carcinomas showing exophytic as well as endophytic growth. Their papillae reveal irregular thickness due to extensive dysplasia. The HG UCs may be regarded as non-invasive even when showing mi- 
Tab. 1. Characterization of PUNLMP and papillary carcinomas as notified by the WHO/ISUP classification (2004).*

\begin{tabular}{|c|c|c|}
\hline PUNLMP & Non-invasive LG UC & Non-invasive HG UC \\
\hline $\begin{array}{l}\text { Regular and symmetric papillary structure, } \\
\text { papillary fusion extremely rare }\end{array}$ & $\begin{array}{l}\text { Less symmetric papillary structure, occasion- } \\
\text { ally variable thickness of papillae as well as } \\
\text { their exophytic growth along with occasional } \\
\text { fusion }\end{array}$ & $\begin{array}{l}\text { Papillary structures upmost irregular, papillary fu- } \\
\text { sion and endophytic growth frequent, papillae show } \\
\text { variable thickness. Microinvasion to lamina propria } \\
\text { possible (a sign of transition to invasive growth) }\end{array}$ \\
\hline $\begin{array}{l}\text { Dysplastic cells seen rarely, the Ki- } 67 \text { positive } \\
\text { rate below } 10 \% \text {. }\end{array}$ & $\begin{array}{l}\text { Basal cell dysplasia frequent, their polarity } \\
\text { and orientation disrupted, the positive rate of } \\
\text { Ki- } 67 \text { cells close to } 25 \%\end{array}$ & $\begin{array}{l}\text { The frequency of dysplastic and/or pleomorphic } \\
\text { cells high, the Ki- } 67 \text { positive rate close to or even } \\
\text { over } 50 \%\end{array}$ \\
\hline $\begin{array}{l}\text { Great majority of cell nuclei shows regular } \\
\text { size and shape, some oval cells may be seen }\end{array}$ & $\begin{array}{l}\text { The oval and/or elongated cell nuclei, more } \\
\text { frequent, the chromatin shows a fine appear- } \\
\text { ance }\end{array}$ & $\begin{array}{l}\text { The enlarged, polymorphic nuclei are abundant } \\
\text { showing coarse chromatin granules and darker stain } \\
\text { (hyperchromasia) }\end{array}$ \\
\hline Mitoses hardly found & Mitoses present but not frequent & Mitosis relatively frequent \\
\hline Surface urothelium cells always present & Surface "umbrella cells" can be still found & Surface urothelium cell are rarely seen \\
\hline $\begin{array}{l}\text { Recurrences possible, but metastasis never } \\
\text { occurs }\end{array}$ & $\begin{array}{l}\text { Recurrences very frequent, invasive growth } \\
\text { is an exception, metastases are rare }\end{array}$ & $\begin{array}{l}\text { Progression to invasive growth frequent, metastases } \\
\text { possible, the surrounding epithelium shows carci- } \\
\text { noma in situ }\end{array}$ \\
\hline
\end{tabular}

*Notice: modified from Montironi et al (42) and Miyamoto et al (39)

Tab. 2. Examples of cell cycle related proteins over expressed in urothelial tumours.

\begin{tabular}{lll}
\hline Protein & Function & Diagnostic role \\
\hline Cyclin D & Regulates G1/S phase transition & Differentiation between LG UC and HG UC \\
\hline p53 & $\begin{array}{l}\text { Transcription factor (TF) for cyclin expression, cell } \\
\text { division and apoptosis regulator }\end{array}$ & $\begin{array}{l}\text { Differentiation between PUNLMP and LG UC; its } \\
\text { mutations important for UC pathogenesis }\end{array}$ \\
\hline pRb & $\begin{array}{l}\text { Regulation of TF release for expression of enzymes } \\
\text { involved in DNA synthesis }\end{array}$ & $\begin{array}{l}\text { Low grade expression might indicate repeated tu- } \\
\text { mor growth }\end{array}$ \\
\hline Survivin & Apoptosis inhibitor & $\begin{array}{l}\text { Over expression in the nuclei correlates with pro- } \\
\text { liferation and dysplasia in HG UC }\end{array}$ \\
\hline p16 & Cyclin inhibitor & $\begin{array}{l}\text { Correlation with cervical but not with urothelial } \\
\text { dysplasia 29, 67 }\end{array}$ \\
\hline Ki-67 & Cofactor for cell DNA synthesis & $\begin{array}{l}\text { Cell proliferation indicator, excellent correlation } \\
\text { with urothelial dysplasia }\end{array}$ \\
\hline
\end{tabular}

croinvasive growth into the lymphatic spaces of lamina propria (i.e. pseudovascular growth) just below the preserved basement membrane [39]. However, some HG UCs (former G2 carcinomas), which show more prominent spread across lamina propria, might be classified as potentially invasive, even when their relationship to lamina muscularis is not clear $(23,51)$.

In order to recognize of the urothelial origin of non-differentiated invasive HG UCs especially within the prostatic area, staining for cytokeratins (such as CK 7 and/or CK20 antigens) was recommended along with the p63 antigen staining $(5,63)$. Within normal urothelium, the CK7 antigen is expressed in many cells, while the CK20 antigen is confined surface "umbrella cells" only. The HMWCK and p63 antigens can be found in basal urothelium cells mainly (10). In contrast, the dysplasic urothelium cells express CK20 as seen in papillary HG UC, where many cells are positive for this antigen. The CK7 and CK20 antigen staining was recommended for differential diagnostic of low-differentiated carcinomas in order to distinguish their adenomatous versus squamous cell origin (40). The CK7 and p63 antigen staining along with the detection of high molecular cytokeratin (HMWCK/clone 34ßE12) were frequently applied to recognize the invasively growing HG UCs in males from their non-differentiated prostatic counterparts $(20,31,50)$.

The correct judgment of cytological signs of urothelium dysplasia needs relatively much experience. For easier orientation,
Tab. 3. Grading of expression for antigens detected by immunohistochemical staining.

\begin{tabular}{ccc}
\hline Grading scale & Estimated number of positive cells & Verbal estimate \\
\hline 4 & $90 \%$ & very frequent \\
3 & $50-89 \%$ & frequent \\
2 & $11-49 \%$ & not frequent \\
1 & $<10 \%$ & very few \\
0 & $<0.1 \%$ & negative \\
\hline
\end{tabular}

several immunohistochemical markers of cell proliferation (such as for Ki-67 antigen) were applied to achieve precise grading. While the Ki-67/MIB-7 antigen correlates well with the cellular DNA synthesis, the other cell division regulator proteins listed in Table 2 are less reliable in this respect. As markers for proliferation of dysplastic urothelium cells, mainly p 53 and Ki-67 proteins were recommended $(55,64)$. Estimation of the proportion of Ki-67 positive cells helps to differentiate between PUNLMP and LG UC on one hand, and especially between LG UC versus HG UC on other hand $(28,53)$. As stressed by Kunjin et al $(30)$, the combination of CK20 and Ki-67 markers for the assessment of urothelium dysplasia is superior to other staining combinations. In this study, we included the p16 staining, which appeared highly relevant for the grading of cervical dysplasia (54), however, here with some disappointing results. 


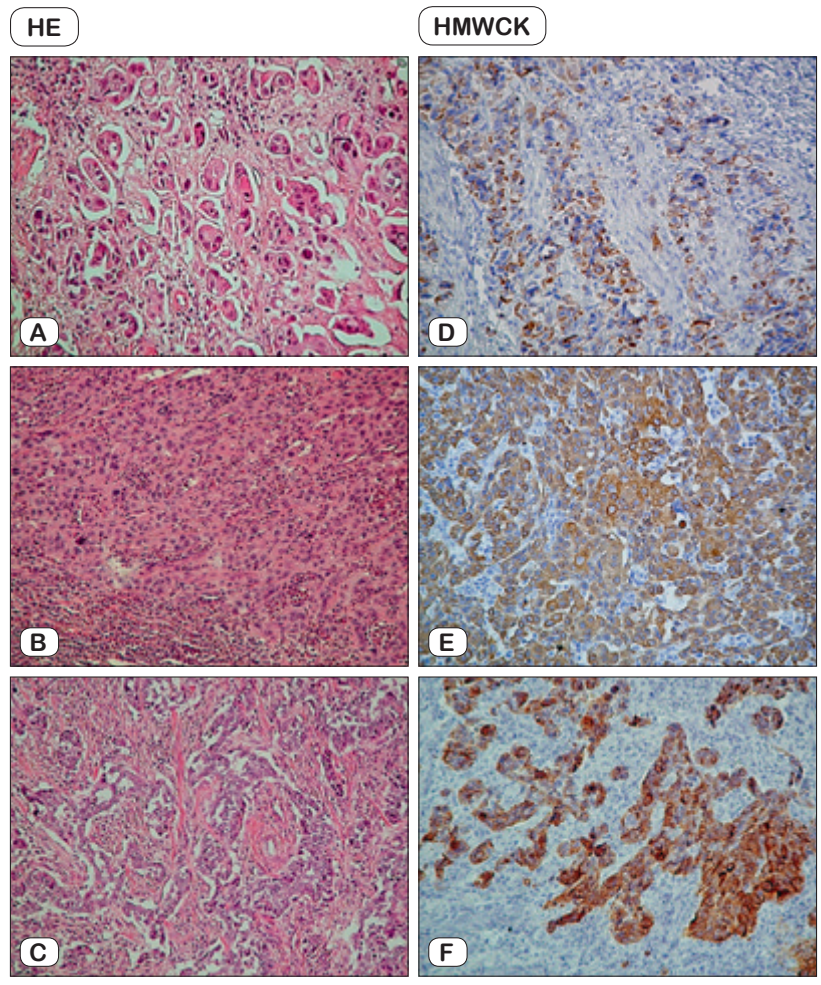

Fig. 1. Examples of low-differentiated invasive urothelium carcinomas (invasive HG UC). HE staining (in the left), HMWCK staining (in the right). A and D-micropapillary carcinoma; B and E-solid carcinoma; $\mathrm{C}$ and $\mathrm{F}$ - pseudoglandular structures.

\section{Materials and methods}

We examined 32 urothelium neoplasms and 7 cases of chronic cystitis from the archive of BB Biocyt as registered in 2009. From the given neoplasms, non-differentiated carcinomas formed more than half $(55 \%)$ of the cases $(17 / 32)$, while the rest were papillary carcinomas showing various degree of dysplasia, originally classified as non-invasive. At least 20 parallel sections ( $4 \mu \mathrm{m}$ thick) were prepared and attached to 10 precoated slides (FLEX Dako).

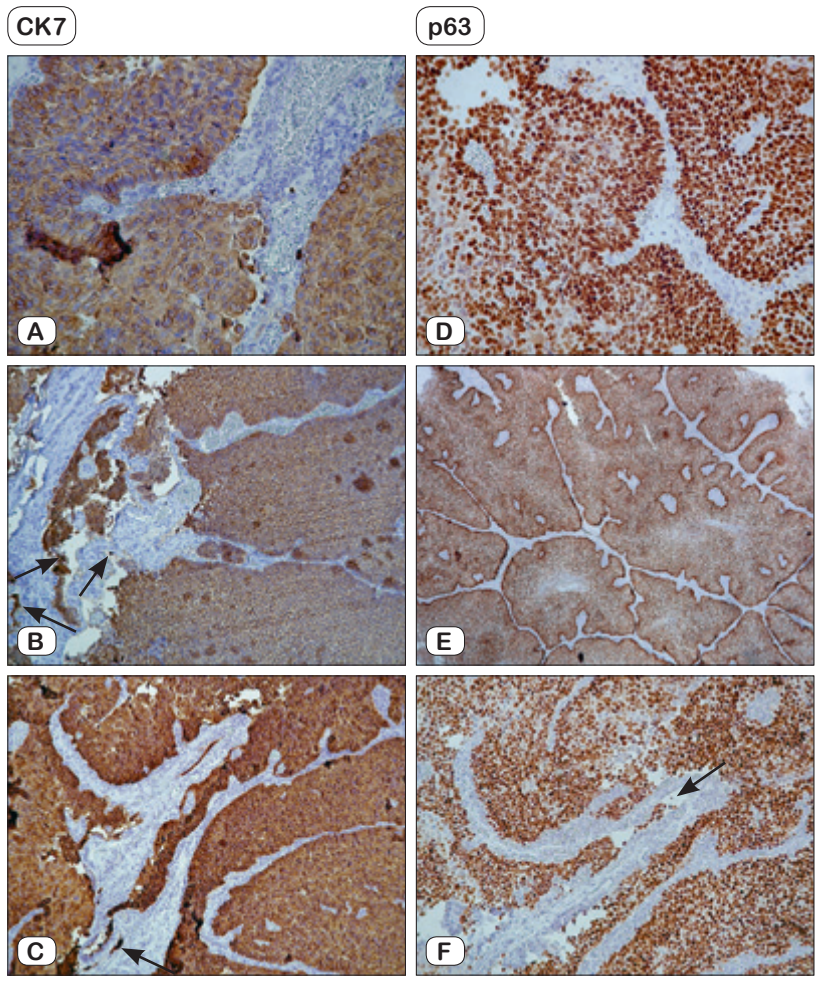

Fig. 2. Examples of microinvasive growth of papillary HG UCs. 2A and 2D: non-invasive HG UC (tumour number 1 from Table 5). A: CK 7 antigen staining (in the left) shows pseudovascular growth; D: p63 antigen staining (in the right), shows endophytic growth with budding of dysplastic urothelium cells into lamina propria. $2 \mathrm{~B}$ and $2 \mathrm{E}$ (tumour number 19 in Table 4): microinvasive growth of the papillary HG UC showing scattered dysplastic cells within lamina propria (arrows) following disruption of the basement membrane. $2 \mathrm{C}$ and $2 \mathrm{~F}$ (tumour number 20 in Table 4): endophytic growth of potentially invasive papillary HG UC showing disseminated dysplastic cells within the lamina propria following disruption of basement membrane (arrow). B and C stained for CK7 antigen; E and F stained for p63 antigen.

At least a single slide was stained with hematoxylin eosin (HE), the rest were handled by immunohistochemical methods. All the slides were deparaffinized, revitalized and rehydrated within the

Tab. 4. Frequency of antigen expression in invasive HG UC tumours.*

\begin{tabular}{|c|c|c|c|c|c|c|c|}
\hline \multicolumn{2}{|c|}{ Number } & \multicolumn{6}{|c|}{ Antigen } \\
\hline & Diagnosis & $\mathrm{p} 16$ & Ki-67 & p63 & CK7 & CK20 & HMWCK \\
\hline \multirow[t]{5}{*}{$\overline{17}$} & low-differentiated HG UC & $0 / 1 * * *$ & $0 / 0$ & $0 / 5$ & $0 / 2$ & $0 / 6$ & $0 / 0$ \\
\hline & & $1 / 1$ & $1 / 0$ & $1 / 0$ & $1 / 1$ & $1 / 4$ & $1 / 1$ \\
\hline & & $2 / 4$ & $2 / 2$ & $2 / 0$ & $2 / 1$ & $2 / 6$ & $2 / 8$ \\
\hline & & $3 / 4$ & $3 / 15$ & $3 / 5$ & $3 / 5$ & $3 / 1$ & $3 / 8$ \\
\hline & & $4 / 7$ & $4 / 0$ & $4 / 7$ & $4 / 8$ & $4 / 0$ & $4 / 0$ \\
\hline \multicolumn{2}{|c|}{ Total } & 17 & 17 & 17 & 17 & 17 & 17 \\
\hline \multirow[t]{5}{*}{3} & papillary HG UC** & $0 / 0$ & $0 / 0$ & $0 / 0$ & $0 / 0$ & $0 / 1$ & $0 / 0$ \\
\hline & & $1 / 1$ & $1 / 0$ & $1 / 0$ & $1 / 0$ & $1 / 0$ & $1 / 0$ \\
\hline & & $2 / 2$ & $2 / 0$ & $2 / 0$ & $2 / 0$ & $2 / 2$ & $2 / 0$ \\
\hline & & $3 / 0$ & $3 / 3$ & $3 / 0$ & $3 / 1$ & $3 / 0$ & $3 / 2$ \\
\hline & & $4 / 0$ & $4 / 0$ & $4 / 3$ & $4 / 2$ & $4 / 0$ & $4 / 1$ \\
\hline \multicolumn{2}{|c|}{ Total } & 3 & 3 & 3 & 3 & 3 & 3 \\
\hline
\end{tabular}

* grading scale described in Table $3, * *$ papillary carcinomas showing microinvasive growth, $* * *$ grade scale/number of tumors 

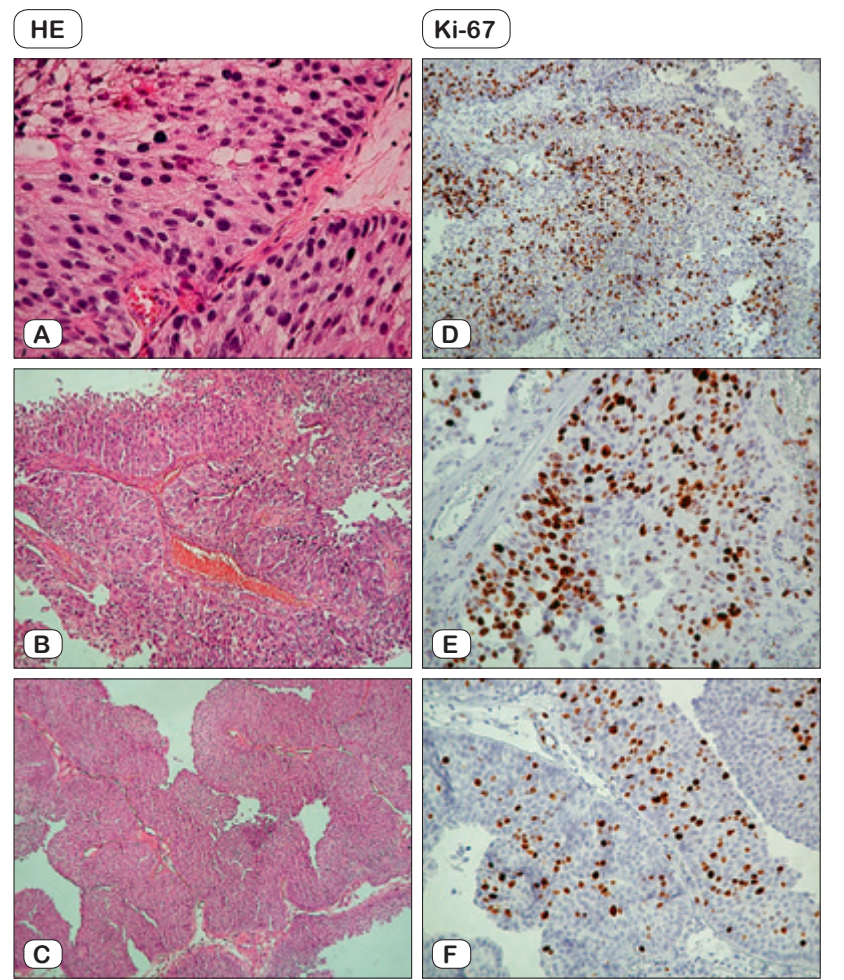

Fig. 3. Different grade of dysplasia by non-invasive HG UC versus LG UC in Ki-67 antigen staining. 3A to 3E: Non-invasive HG UC of high grade malignant potential. In the left: $\mathrm{HE}$ staining (3B and $3 \mathrm{C}$ ) shows the polymorphism of the nuclei of dysplastic cells. In the right: Ki-67 staining (3D and 3E) points at the nuclear polymorphism of dysplastic cells. $3 \mathrm{C}$ and $3 \mathrm{~F}$ : Non-invasive $\mathrm{LG} \mathrm{UC}$ revealing relatively symmetric papillary structure (HE stain, 3C). By Ki-67 staining (in the right, $3 \mathrm{~F}$ ) the nuclei are smaller and more uniform, the positive rate being below $25 \%$.

PT Link equipment (Dako). Before staining, they were treated with $3 \% \mathrm{H}_{2} \mathrm{O}_{2}$ (to remove the endogenous peroxidase). In the first trial, the sections were treated with monoclonal antibodies (MoAb) against CK7, CK20, HMWCK, p63 and Ki-67 antigens (Dako), while one control slide was treated with the washing buffer (phosphate buffered saline, PBS) only. The MoAbs were used in dilutions provided by the manufacturer (being a part of corresponding kits). After washing 3 times, the slides were overlaid with the second labelled antibody (anti-mouse/Px) for 45 minutes, washed again three times and finally, treated with the chromogen solution (DAB, provided by each kit). The p16 antibody kit was purchased from the CINTec. One slide was treated with p16 MoAb
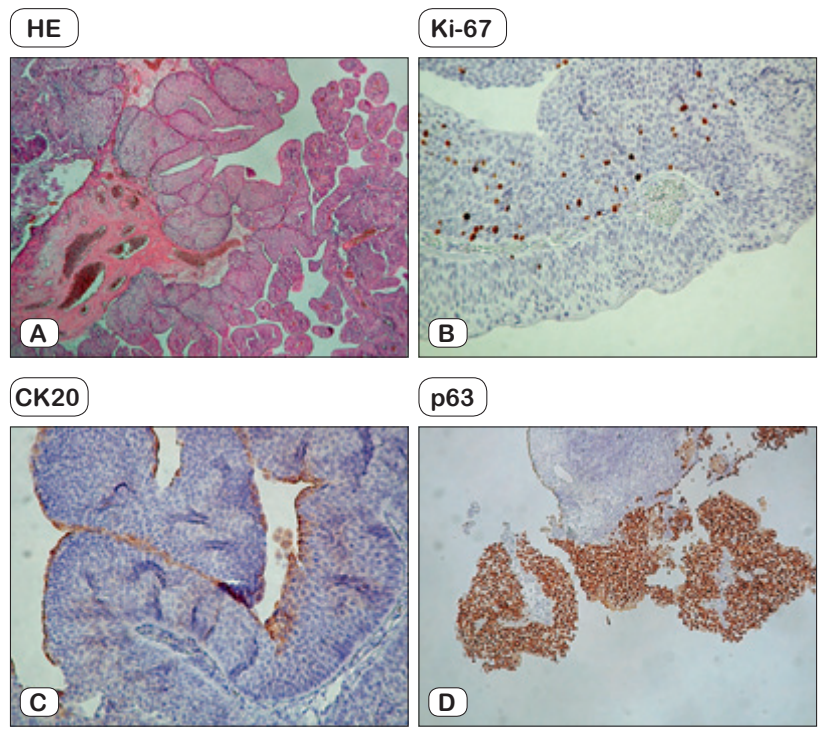

p63
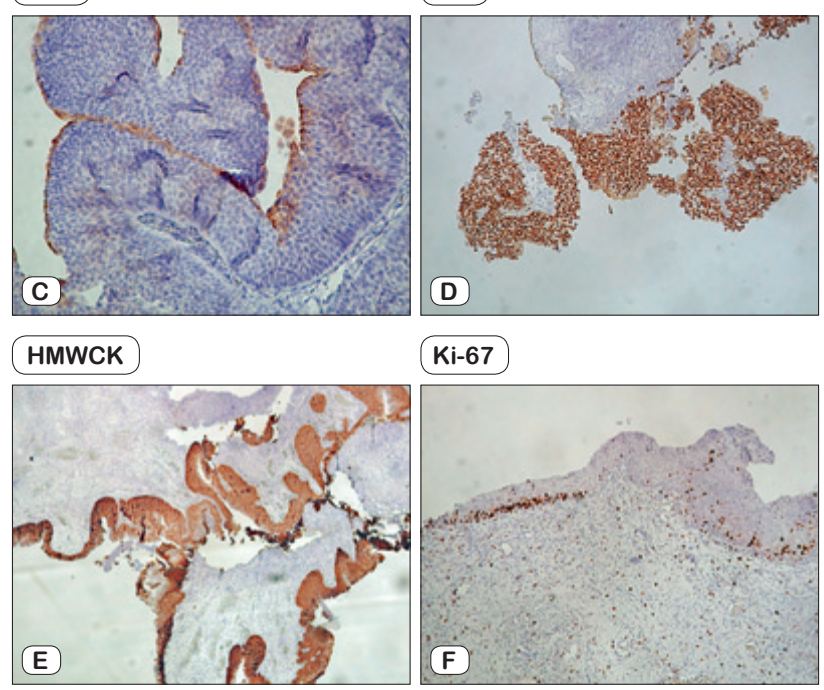

Ki-67

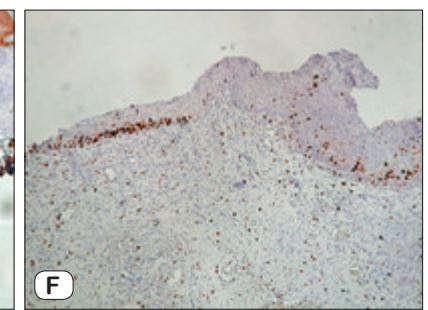

Fig. 4. PUNLMP and the reactive urothelium in chronic cystitis. $4 \mathrm{~A}$ to 4C: papillary urothelial neoplasm of low malignant potential (PUNLMP) at HE staining (A), Ki-67 staining (B) and CK20 antigen staining (C). 4 D: urothelium hyperplasia (p63 antigen staining) . 4E: polypoid urothelium hyperplasia (HMWCK antigen staining). Fig. 4F: reactive focal urothelium hyperplasia (at the right side of the Figure the Ki-67 antigen staining shows irregular distribution of proliferating cells, whereas the normal urothelium reveals the Ki-67 cells located at basal layer).

after the same pretreatment procedure as described above, while another slide was first treated with the "blocking reagent" from Dako (to prevent nonspecific staining). One negative control slide was overlaid with PBS only. Then, the immunostaining procedure was continued with the second Px-labeled antibody as described above. The parallel slides (numbered 1-10) were viewed in the microscope Nikon Eclipse 200 (objectives 4x, 10x, 20x and 40x) and photographed. For watching more details, the microscope was equipped with a glycerin immersion objective $60 \mathrm{x}$. The frequency

Tab 5. Frequency of antigen expression in non-invasive HG UC tumours.*

\begin{tabular}{|c|c|c|c|c|c|c|c|}
\hline \multicolumn{2}{|c|}{ Number } & \multicolumn{6}{|c|}{ Antigen } \\
\hline & Diagnosis & p16 & $\mathrm{Ki}-67$ & p63 & CK7 & CK20 & HMWCK \\
\hline \multirow[t]{5}{*}{5} & Non-invasive HG UC** & $0 / 0$ & $0 / 0$ & $0 / 0$ & $0 / 0$ & $0 / 0$ & $0 / 0$ \\
\hline & & $1 / 2$ & $1 / 0$ & $1 / 0$ & $1 / 1$ & $1 / 2$ & $1 / 1$ \\
\hline & & $2 / 1$ & $2 / 0$ & $2 / 2$ & $2 / 0$ & $2 / 0$ & $2 / 1$ \\
\hline & & $3 / 2$ & $3 / 5$ & $3 / 2$ & $3 / 1$ & $3 / 3$ & $3 / 3$ \\
\hline & & $4 / 0$ & $4 / 0$ & $4 / 2$ & $4 / 3$ & $4 / 0$ & $4 / 0$ \\
\hline \multicolumn{2}{|c|}{ Total } & 5 & 5 & 5 & 5 & 5 & 5 \\
\hline
\end{tabular}

\footnotetext{
* grading scale described in Table 3
} 
Tab. 6 Frequency of antigen expression in non-invasive LG UC and PUNLMP tumors.*

\begin{tabular}{|c|c|c|c|c|c|c|c|}
\hline \multicolumn{2}{|c|}{ Number } & \multicolumn{6}{|c|}{ Antigen } \\
\hline & Diagnosis & p16 & Ki-67 & p63 & CK7 & CK20 & HMWCK \\
\hline \multirow[t]{5}{*}{4} & Non-invasive LG UC & $0 / 0$ & $0 / 0$ & $0 / 0$ & $0 / 0$ & $0 / 1$ & $0 / 0$ \\
\hline & & $1 / 0$ & $1 / 0$ & $1 / 0$ & $1 / 0$ & $1 / 2$ & $1 / 0$ \\
\hline & & $2 / 2$ & $2 / 4$ & $2 / 0$ & $2 / 0$ & $2 / 1$ & $2 / 2$ \\
\hline & & $3 / 1$ & $3 / 0$ & $3 / 3$ & $3 / 1$ & $3 / 0$ & $3 / 2$ \\
\hline & & $4 / 1$ & $4 / 0$ & $4 / 1$ & $4 / 3$ & $4 / 0$ & $4 / 0$ \\
\hline \multicolumn{2}{|c|}{ Total } & 4 & 4 & 4 & 4 & 4 & 4 \\
\hline \multirow[t]{5}{*}{3} & PUNLMP & $0 / 0$ & $0 / 0$ & $0 / 0$ & $0 / 0$ & $0 / 0$ & $0 / 0$ \\
\hline & & $1 / 0$ & $1 / 3$ & $1 / 0$ & $1 / 0$ & $1 / 3$ & $1 / 0$ \\
\hline & & $2 / 3$ & $2 / 0$ & $2 / 2$ & $2 / 1$ & $2 / 0$ & $2 / 3$ \\
\hline & & $3 / 0$ & $3 / 0$ & $3 / 1$ & $3 / 0$ & $3 / 0$ & $3 / 0$ \\
\hline & & $4 / 0$ & $4 / 0$ & $4 / 0$ & $4 / 2$ & $4 / 0$ & $4 / 0$ \\
\hline \multicolumn{2}{|c|}{ Total } & 3 & 3 & 3 & 3 & 3 & 3 \\
\hline
\end{tabular}

* grading scale described in Table 3

of positive cells per 1000 tumour cells was estimated for each antigen staining procedure in each tumour and the values were registered as presented in the Table 3.

\section{Results}

\section{Low-differentiated urothelial carcinomas}

The great majority of invasive UCs (also referred to as invasive HG UC), were non-differentiated neoplasms consisting of pleomorphic cells with large nuclei and abundant cytoplasm. Low-differentiated UCs clearly infiltrated the muscular layer of urinary bladder. Unfortunately, no clinical data describing the extent of their invasive growth outside of urinary bladder wall were available. Histologically, a proportion of invasive HG UCs could be classified as of micropapillary type (Figs 1A and 1D). Other invasive HG UCs were referred to as nested type (Figs $1 \mathrm{~B}$ and 1E), since they consisted of solid strands and/or globular nests of pleomorphic cells. Further invasive HG UCs consisted of irregularly distributed pleomorphic cells grouped into the pseudoglandular formations (Figs $1 \mathrm{C}$ and $1 \mathrm{~F}$ ), while additional ones were composed of anaplastic cells showing sarcoma like growth. All low-differentiated UCs expressed the HMWCK antigen, while the other urothelium markers were less regularly found. As shown in the Table 4, the CK7 antigen was missing in 2 cases (10\%), the CK20 and p63 antigens were not seen in 6 or 5 cases (30\%). From differential diagnostic point of view, at least two urothelium markers were always present distinguishing the tumours in question from low-differentiated prostata carcinomas. When the CK7 and CK20 antigens were absent, the p63 and HMWCK markers were positive; if the p63 antigen was not found, the HMWCK and CK7 markers (occasionally also CK20) were present (Tab. 4). The cell proliferation marker $\mathrm{Ki}-67$, as a rule, was positive in many nuclei (over $50 \%$ ) in each low-differentiated carcinoma at a frequency similar to the papillary non-invasive HG UCs. Noteworthy, three relatively differentiated papillary HG UCs, which showed microinvasive growth into the lamina propria (as detected by p63 and/ or CK7 staining) (Figs 2B to 2C), were classified as potentially invasive and therefore included into Table 4.

\section{Non-invasive papillary urothelial carcinomas}

The cardinal sign of papillary HG UCs is the irregular structure and uneven distribution of dysplatic urothelium cells forming clusters of variable thickness. In non invasive UCs revealing a high grade of malignant potential (HG UC), the enlarged nuclei of dysplastic cells were uneven in size, showed oval or elongated shape and dark basophilia due to hyperchromatic appearance of large granular chromatin (Figs 3A and 3B). The variable size and shape of the nuclei in dysplastic cells could be highlighted by positive Ki67 staining. The Ki-67 positive nuclei dominated in the majority of dysplastic cells covering the papillae, comprising over the half (50 $\%$ ) of the tumour cells (Figs 3C and 3D). As summarized in the Table 5 , the typical findings in non-invasive HG UCs were as follows: 1. The staining for Ki-67 antigen, which was positive in over $50 \%$ of tumour cells and correlated well with the degree of dysplasia. 2. In contrast, the $\mathrm{p} 16$ antigen positive rate did not correlate with the degree of malignant potential. In at least five HG UC tumours (regardless whether invasive or non-invasive) only a few single cells were positive for this antigen. 3. The staining for $\mathrm{p} 63, \mathrm{CK} 7$ and HMWCK antigens was regularly positive in all non-invasive HG UC tumours.

The papillary carcinomas of low malignant potential (noninvasive LG UC) showed a more regular papillary structure. The dysplastic cells occupied mainly a slim strip along the basement membrane being less abundant and showing nuclei just slightly increased in size (Fig. 3C). Their proportion, as judged according to the Ki-67 positive staining, was clearly lower as compared with the above mentioned non-invasive HG UC tumours; in general, the Ki-67 positive rate did not exceed the value of $25 \%$ (Tab. 6). However, LG UCs still showed some degree of variability in the shape and thickness of their papillae, which occasionally even fused with each other. The cell proliferation marker Ki-67 pointed at a clear decrease from HG UC tumours ( $>50 \%)$ through LG UC tumours (about $25 \%$ or less) to PUNLMPs (see below).

\section{Papillary urothelium neoplasms of low malignant potential} (PUNLMP) and reactive hyperplasia

Some papillary tumours cannot be regarded for carcinoma, since they show a quite regular differentiated structure (Fig. 4A). 
The number of cell layers covering the papillae is slightly over 7 , which number is regarded for the maximal thickness of urothelium. The PUNLMP cells nearly uniform in size form quite regular lines and possess slightly enlarged oval shaped nuclei distributed perpendicularly to the basement membrane. The positive rate of Ki-67 stained cells in the PUNLMP is relatively low, as a rule, it does not exceed $10 \%$ (Tab. 6). Occasionally, the CK20 antigen can be found at apical location similarly to typical surface "umbrella" cells, while the HMWCK antigen is distributed rather at basal localization.

The criterion of different positive rate of Ki-67 antigen could not be used to distinguish between PUNLMP and urothelium hyperplasia. The main criterion for the latter was the positive p63 antigen staining of basal and parabasal urothelium cells along with the normal localization of the CK7 and HMWCK positive cells. In the case of polypoid hyperplasia, the urothelium covered finger-like protrusions of urinary mucosa (Fig. 4D). The hyperplastic mucosa might have shown a relatively abundant number of Ki-67 positive cells at the rate ranging slightly over $10 \%$, however, neither the signs of dysplasia nor the growth or a real papillary neoplasm could be noticed in such cases. Noteworthy, in the so called miropapillary hyperplasia, the papillae-like structures lack their own capillary supply (Fig. 4E). When areas of denudation were covered with a single line of dysplastic Ki-67 positive cells, this finding could be interpreted as carcinoma in situ, as found in one out of our 7 chronic cystitis cases. Taken together, for the diagnosis of hyperplasia or metaplasia, the p63 staining was useful, while for the recognition of any kind of dysplasia, the Ki-67 antigen could highlight the altered nucleus to cytoplasm ratio.

\section{Discussion}

The CK 7 staining was positive in all papillary carcinomas and PUNLMP papillomas, the only exception were 2 out 17 lowdifferentiated carcinomas. These results are in accord with the findings that this antigen used to be expressed in tumours of epithelial origin with the exception of cervical carcinomas, renal carcinomas, prostate and colon carcinomas $(8,9)$. Cytokeratin 20 was reported to occur in $70-80 \%$ of transitional cell carcinomas (6). In accord with this, we have not found this antigen in 6 out 17 low differentiated carcinomas and in 2 out 12 papillary carcinomas (regardless of the grade of dysplasia), which means 27.5 $\%$ of negative UCs. In cases of urothelial hyperplasia as well as in PUNLMP, the presence of CK20 antigen within surface "umbrella" cells was of diagnostic importance (3). The p63 antigen was a helpful diagnostic marker in HG UC neoplasms to demonstrate the microinvasive growth into the lamina propria (Figs $2 \mathrm{~A}-2 \mathrm{~F}$ ). In invasive low-differentiated UC, the p63 expression declines (63), this phenomenon was also noticed in our material (Tab. 4).

As described by Margolis et al $(35,36)$ in a large cohort of 713 patients, the Ki-67 antigen was probably the most reliable proliferation marker documenting an aggressive growth, tumour recurrence and a worse prognosis. The Ki-67 protein is expressed in nuclei of cells, which synthesize DNA (in the S phase). Its expression correlates precisely with the extent of ${ }^{3} \mathrm{H}$-thymidine and/or 5-bromodeoxyuridine (BrdU) incorporation into the newly copied chro- mosomal DNA $(22,32)$. In cases on non-invasive HG UC and LG $\mathrm{UC}$, the Ki-67 positive rate (index) helps to discriminate between their high grade versus low grade malignant potential based on the estimated number of dysplastic tumour cells. Before the acceptance of the WHO/ISUP classification, some authors described the Ki67 stain as helpful in recognizing the difference between G1 and G2 papillary carcinomas (13) and pointed out that the Ki-67 was a better marker than the p53 stain (52). The Ki-67 stain represents a useful diagnostic tool, especially in cases, when small tumour fragments only are at disposal. Tables 4, 5 and 6 clearly show that the Ki-67 positive rate decreased from papillary HG UC through LG UCs to PUNLMP. In addition to this, the Ki-67 staining is useful for identification of dysplastic cells, which can replace the denuded urothelium in flat in situ carcinoma (pTis). Either the Ki67 positive and/or the p53 antigen positive cells may form a single line of dysplastic or even pleomorphic cells with irregular shaped nuclei showing pagetoid spread $(33,37,49)$. If such cells form more than a single layer, the CK20 antigen might be also expressed (46). Both, Ki-67 as well as CK20 staining were useful markers for differentiation between dysplasia on one hand, non-neoplastic hyperplasia and/or reactive urothelium atypia on other hand (42).

Another histological sign of cardinal importance is the invasive growth clearly present by all low-differentiated UCs (Figs $1 \mathrm{~A}-1 \mathrm{~F})$. In these clearly invasive low-differentiated carcinomas as well as in their metastases, the expression of metallothionein was demonstrated as a highly reliable marker (59). The matter of controversy is the essentially non-invasive HG UCs, clinically pT1 grade, which shows endophytic growth of various extent into the lamina propria. Some authors claimed that the depth of endophytic growth into the subepithelial connective tissue might be of prognostic importance; they suggested to classify the pT1 tumours into the stages pT1a and pT1b $(12,61)$. Nevertheless, this subdivision has not been widely accepted. Certain forms of microinvasion (such as pseudovascular growth) can be classified as non-invasive provided that the basement membrane remains preserved (Figs $2 \mathrm{~A}$ and 2D). Another kind of subepithelial growth of HG UCs with the basement membrane disrupted (Figs $2 \mathrm{~B}-2 \mathrm{~F}$ ) might be regarded as invasive, since such tumours would continue their growth into deeper structures with a probability of $25-29 \%(27,34)$. At histological examination, the adipose tissue may be seen just adjacent to the urothelium, and not even the position of the muscle layer is always clear-cut [51]. Regarding these considerations, we list in the Table 4 (but still separately) the 3 papillary HG UCs, because they showed more extensive microinvasion into the lamina propria.

Our results showed that the p16 antigen staining was not a relevant marker for the detection of dysplastic urothelium cells in contrast to cervical and/or anal squanous cell dysplasia. Some authors recommend the p16 antigen demonstration in small cell UCs, especially if they are negative for $\mathrm{p} 63$ and/or CK20 proteins. Nevertheless, the $\mathrm{p} 16$ polypeptide was seen in many UCs, pointing out the possibility that the 16 inhibitor kinase was over expressed not only in association with the HPV-coded E7 oncogen. Clearly, HPV was found very rarely causing UC (7). The virus possible related to papillary UCs is the human papovavirus called BKV $(24,65)$. The recently developed DNA tests can distinguish the sequence 
of JC virus as compared to the BK virus (44) and seem promising for the elucidation of the possible role of certain BKV variants in the pathogenesis of UCs. During human papovavirus latency, a portion of the genome encoding a part of $\mathrm{T}$ antigen (called small $t$ ) could become integrated into the nuclei of infected urothelium cells. The expression of corresponding protein could play some role in the transformation process of the basal urothelium cells.

More than the exogenous BKV, endogenous mutations of $\mathrm{p} 53$, $\mathrm{pRb}$ and/or other regulatory proteins listed in the Table 2, might be of importance for UC pathogenesis. The most frequently discussed mutations concern the intron P2RY5 of the pRb gene (14, $15,16)$. PUNLMP seems to appear in response to benign and/or reactive hyperplasia, while the carcinoma in situ might be the origin for HG UC, which finally may result into invasive and later on low-differentiated HG UCs (25). In addition to single mutations, foreign DNA fragments and/or endogenous repetitive DNA motifs could accumulate in the nuclei of pluripotent (precursor) urothelium cells causing what is called a microsatellite instability (MSI). These changes along with the deletions in $\mathrm{p} 53$ protein genome may lead to a precancerous state, which could change into real carcinoma, if they occur in both chromosome alleles.

\section{References}

1. Amin MB, Gomes JA, Yang RH et al. Urothelial transitional cell carcinoma with endophytic growth patterns: a discussion of patterns of invasion and problems associated with assessment of invasion in 18 cases. Am J Surg Pathol 1997; 21: 1057-1068.

2. Angolo, JC, Lopez JI, Grignon G. Muscularis mucosa differentiates two populations with different prognosis in stage T1 bladder cancer. Urology 1995; 45: 47-53.

3. Barbisan F, Santinelli, A Mazzucchelli R et al. Strong immnohistochemical expression of fibroblast growth factor receptor 3, superficial staining pattern of cytokeratin 20 and low proliferative activity define those papillary urothelial neoplasms of low malignant potential that do not recur. Cancer 2008; 112: 636-644.

4. Bean SM, Eltourn I, Horton DK et al. Immunohistochemical expression of p16 and Ki-67 correlates with the degree of anal intraepithelial neoplasia. Am J Surg Pathol 2007; 31: 555-561.

5. Buza N, Cohen PJ, Pewi Hui, Parkash V. Inverse p16 and p63 expression in small cell carcinoma and high grade urothelial cell carcinoma of the urinary bladder. Int J Surg Pathol 2010; 18: 94-102.

6. Cassel A, Rahat MA, Lahat $\mathbf{N}$ et al. Telomerase activity and cyrokeratin as markers for the detection and follow up of transitional cell carcinoma: an unfulfilled promise. J Urol 2001; 166: 841-844.

7. Chetsanga C, Malmstrom PU, Gyliensten U et al. Low incidence of human papillomavirus type 16 DNA in bladder tumor detected by polymerase chain reaction. Cancer 1992; 69: 1206-1211.

8. Chu PG, Emerald WU, Weiss LM. Cytokeratin 7 and cytokeratin 20 expression in epithelial neoplasms: a survey of 435 cases. Mod Pathol 2000; 13:962-972.

9. Chu PG, Weiss LM. Keratin expression in human tissues and neoplasms. Histopathology 2002; 40: 403-439.

10. Chu, PG, Weiss, LM. Tumors of the urinary bladder. 301-320. In: Modern Immunohistochemistry. Cambridge illustrated Surgical Pathology, Cambridge University Press, 2009.

11. Chen Y-H, Jianling J, Tu, Kao J et al. Survivin as a useful adjunct marker for grading of papillary urothelial carcinoma. Arch Pathol Lab Med 2008; 132: 224-231.
12. Cheng Liang, Neumann RM, Weaver AL et al. Predicting cancer progression in patients with satge T1 bladder carcinoma. J Clin Oncol 1999; 17: $3182-3187$.

13. Cheville JC, Terrell, RB, Cohen MB. Use of proliferative markers Ki67(MIB-1) and proliferating cell nuclear antigen (PC10) in transitional cell carcinoma of the renal pelvis. Mod Pathol 1994; 7: 794-800.

14. Cordon-Cardo C, Cote RJ, Sauter G. Genetic and molecular markers of urothelial premalignancy and malignancy. Scand J Urol Nephrol Suppl 2000; 82-93.

15. Corlon-Cardo C. Molecular alterations associated with bladder cancer initiation and progression. Scand J Urol Nephrol Suppl 2008; 218: 154-165.

16. Crawford JM. The origins of bladder cancer. Lab Invest 2008; 88: 686-693.

17. Eble JN, Sauter G, Epstein JI et al. World Health Organization Classification of Tumors. Pathology and Genetics of Tumors of the Urinary System and Male Genital Organs. Lyon IARC Press, 2004.

18. Edge SB, Byrd, DR, Compion CC et al. Urinary bladder, pp.5669-577, in: Cancer Staging Handbook. 7th ed., Springer, 2010.

19. Epstein JI, Amin, MB, Reuter VR et al. Bladder Consensus Conference Committee. The World Health Organization/International Society of Urological Pathology: Consensus classification of urothelial (transitional cell) neoplasms of the urinary bladder. Am J Surg Pathol 1998; 22: 1435-1448.

20. Esuvarathan K, Chiong, E, Tahmboo ThP et al. Predicitve value of p53 and $\mathrm{Rb}$ expression in superficial bladder cancer patients treated withj BCG and interpheron-alpha. Cancer 2007; 109: 1097-1105.

21. Genega EM, Hutchinson B, Reuter VE et al. Immunophenotype of high grade prostatic adenocarcinoma and urothelial Carcinoma. Mod Pathol 2000; 13: 1186-1191.

22. Gratzner HB. Monoclonal antibody to 5-bromodeoxyuridine and 5-diododeoxyuridine: a new reagent for detection of DNA replication. Science 1992; 218: 474-475.

23. Humphrey PA. Urinary bladder pathology: an update. Ann Diagn Pathol 2004; 6: 380-389.

24. Harris KF, Chang E, Christensen JB, Impariale MJ. BK virus as a potential co-factor in human cancer. Dev Biol Stand 1998; 94: 81-91.

25. Hartmann A. Molecular changes in development and progression of urothelial carcinoma. Verh Dtsch Ges Pathol 2003; 87: 172-184.

26. Kalanatari M, Ahmadnia, H. p53 overexpression on bladder urothelial neoplasms. New aspect of World health Organization/International Society of Urological Pathology Classification. Urol J 2007; 4: 230-239.

27. Kaubisch $\mathbf{S}$, Lum BL, Reese $\mathbf{J}$ et al. Stage $\mathrm{T} 1$ bladder cancer: grade is the primary determinant for risk of muscle invasion. J Urol 1991; 146: 28-31.

28. Korneev IA. The prognostic value of Ki- 67 proliferation index in transitional cell carcinoma of renal pelvis and ureter. Vopr Onckol 2005; 51 : 211-215.

29. Kruger S, Mahnken A, Kausch I, Feller, AC. P16 immunoreactivity is an independent predictor of tumor progression in minimally invasive urothelial bladder carcinoma. Eur Urol 2005; 47: 463-467.

30. Kunju LP, Lee CT, Montie J, Shah RB. Utility of cytokeratin 20 and Ki-67 as markers of urothelial dysplasia. Pathol Int 2005; 55: 248-254.

31. Kunju LP, Mehra R, Snyder M, Shah R. Prostate-Specific Antigen, High Molecular Weight Cytokeratin (clone 34bE12) and/or p63: An Optimal Immunohistochemical Panel to Distinguish Poorly Differentiated Prostatae Adenocarcinoma from Urothelial Carcinoma. Am J Clin Pathol 2006; 125: 675-681.

32. Limas C, Bigler, A, Bair R et al. Proliferative activity of urothelial neoplasma: comparision of BrdU incorporation, Ki-67 expression, and nucleolar organizer regions. J clin Pathol 1993; 46: 159-165. 
$431-438$

33. Mallofré C, Castillo M, Morente V, Sole M. Immunohistocehmical expression of CK20, p53 and Ki-67 as objective markers of urothelial dysplasia. Modern Pathol 2003; 16: 187-191.

34. Malstrom PU, Busch, G, Norien, BJ. Recurrence, progression and survival in bladder cancer. A retrospective analysis of 232 patients with greater than or equal to 5-year follow-up. Scand J Urol Nephrol 1987; 21: 185-195.

35. Margulis V, Shariat SF, Ashfaq R et al. Ki-67 is an independent predictor of bladder cancer outcome in patients treated with radical cystectomy for organ confined disease. Clin Cancer Res 2006; 12: 7369-7385.

36. Margulis V, Lotan, Y, Karakiewicz PI et al. Multi-institutional validation pof the predictive value oif Ki-67 labeling index in patients with urinary bladder cancer. J Natl Cancer Inst 2009; 101: 114-119.

37. McKenney JK, Desai S, Cohen C, Amin MB. Discriminatory Immunohistochemical staining of urothelial carcinoma in situ and non-neoplastic urothelium: and analysis of cytokeratin 20, p53 and CD44 antigens. Am J Surg Pathol 2001; 25: 1074-1078.

38. Mhavech P, Greloz V, Oppikofer, $\mathbf{C H}$ et al. Expression of cell cycle proteins in $\mathrm{T} 1 \mathrm{a}$ and $\mathrm{T} 1 \mathrm{~b}$ urothelial bladder carcinoma and their value in predicting tumor progression. Cancer 2004; 100: 2387-2379.

39. Miyamoto H, Miller, JS, Fajardo DA et al. Noninvasive papillary urothelial neoplasms: The 2004 WHO/ISUP classification system. Pathol International 2010; 60: 1-v8.

40. Moll, R, Dive, M, Langheim L. The human keratins: biology and pathology. Histochem Cell Biol 2008; 129: 705-733.

41. Montironi E, Lopez-Beltran A, Mazzucchelli R, Bostwici DG. Classification and grading of the non-invasive urothelial neoplasms: recent advances and controversies. J Clin Pathol 2003; 56: 91-95.

42. Montironi R, Mazzuccheli R, Scarpelli M. Morphological diagnosis of urothelial neoplasms. J Clin Pathol 2007; 63: 1-9.

43. Mostofi FK, Sobin LH, Tordoni H. Histological Typing of Urinary bladder tumors, pp. 15-17, in: International Histological Classification of Tumors No. 10, World Health Organization Geneva, Switzerland, 1973.

44. Moret $\mathbf{H}$, Brodard V, Betrangher $\mathrm{C}$ et al. New commercially available PCR and microplate hybridization assay for detection and differentiation of human polyomaviruses $\mathrm{JC}$ and $\mathrm{BK}$ in cerebrospinal fluid, serum and urine samples. J Clin Microbiol 2006; 44: 1305-1309.

45. Murphy WM, Busch C, Algaba F. Intraepithelial lesions of urinary bladder: morphologic considerations. Scand J Urol Nephrol Suppl 2000; 205: 67-71

46. Murphy WM, Grignon DJ, Perlman EJ. Tumors of the Kidney, Bladder and related Urinary Structures. AFIP Atlas of Tumor Pathology, IVth series, fascicle 1, American Registry of Pathology, Washington, DC, 2004.

47. Nese N., Gupta R., Bui MH, Amin MB. Carcinoma in situ of the urinary bladder: review of clinicopathologic characteristics with an emphasis on aspects related to molecular diagnostic techniques and prognosis. J Natl Comp Canc Netw 2009; 7: 48-57.

48. Okamura K, Mizake K, Koshikawa T, Assi J. Growth fractions of transitional cell carcinoma of the bladder defined by the monoclonal antibody Ki-67. J Urol 299; 144: 875-858.

49. Owens CL, Epstein JI. Significance of denuded urothelium in papillary urothelial lesions. Am J Surg Pathol 2007; 31: 298-303.

50. Parker DC, Folpe AL, Bell J et al.: Potential utility of uroplakin III, thrombomodulin, high molecular weight cytokeratin, cytokeratin 20 in noninvasive, invasive and metastatic urothelial (transitional cell) carcinomas. Am J Surg Pathol 2003; 27: 1-10.

51. Philip AT, Amino MB, Tamboli $P$ et al. Intravesical adipose tissue: a quantitative study of its presence and location with implications for therapy and prognosis. Am J Surg Pathol 2000; 24: 1286-1290.
52. Pich A, Chiusa L, Formiconi A et al. Proliferative activity is the most significant predictor of recurrence in noninvasive papillary urothelial neoplasms of low malignant potential and grade 1 papillary carcinomas of the bladder. Cancer 2002; 95: 784-790.

53. Quintero, A, Alvarez-Kindelan, J, Luque RJ et al. Ki-67/MIB1 labeling index and the prognosis of primary $\mathrm{Ta} / \mathrm{T} 1$ urothelial cell carcinoma of the bladder. J clin Pathol 2006; 59: 83-88.

54. Rajčáni J, Adamkov M, Hybenová J, Moráveková E, Lauko L, Felcanova D, Bencat M. Detekcia regulačného proteínu p16/INK4A v dysplastickom dlaždicovom epiteli krčka maternice ako diagnostický nástroj prevencie karcinómu. Čes Slov Patol 2009; 48: 101-107.

55. Rosenblatt R., Jonmarker S., Lewensohn R., Egevad L., Kälkner KM, Nilsson S., Vladman A., Ullén A. Current status of prognostic immunohistochemical markers for urothelial bladder cancer. Tumour Biol 2008; 29:311-322.

56. Sauter G, Algaba F, Amin MB et al. Tumors of the urinary system. 89-57. In: Epstein, JI, Eble JN, Seesternbenn I, Sauter G (Eds). World Health Organization Classification of Tumors, Pathology and Genetics. Tumors of Urinary System and Male Genital Organs. Lyon IARC Press, 2004.

57. Skagias L, Politi, E, Karameris A et al. Survivin expression as a strong indicator of recurrence in urothelial bladder cancer. Predictive value of nuclear versus cytoplasmic staining. Anticancer Res 2009; 29: 4163-4167.

58. Shariat SF, Ashfaq R, Karakiewicz PI. Survivin expression is associated with bladder cancer presence, stage, progression and mortality. Cancer 2007; 109: 1106-1113.

59. Siu LL, Banerjee, D, Khurana RJ et al. The prognostic role of $\mathrm{p} 53$, metallothionein, P-glycoprotein, and MIB-1 in muscle-invasive urothelial transitional cell carcinoma. Clin Cancer Res 1998; 4: 559-563.

60. Smith, ND, Rubenstein, JN, Eggener, SE, Kozlowsky JM. The p53 tumor suppressor gene and nuclear protein: basic science review and relevance in the management of bladder cancer. J Urol 2003; 189: 1209-1228.

61. Smits G, Schaefsma E, Kiemenez L et al. Microstaining of pT1 transitional cell carcinoma of the bladder: identification of subgroups with distinct risks of progression. Urology 1998; 52: 1009-1013.

62. Spyratos F, Ferrero-pous, M, Trassard M et al. Correlation between mIB-1 and other proliferation markers: clinical implications of the MIB-1 cut-off value. Cancer 2002; 94: 2151-2159.

63. Stepan A, Margaritescu C, Simionescu C, Ciurea R. E-adherin and p63 Immnoexpression in dysplastic lesions and urothelial carcinomas of the bladder. Rom J Morphol Embryol 2009; 50: 461-65.

64. Sun W, Zhang PL, Herrera GA. p53 protein and Ki-67 overexprssion in urothelial dysplasia of bladder. Appl Immunohitochemistry Mol Morphol 2002; 10: 327-331.

65. Tognon M, Corallini A, Martihni F et al. Oncogenic transformation by BK virus association with human tumors. Oncogene 2003; 22: 5192-5200.

66. Tut, VM, Braithwaite KL, Angua B et al. Cyclin D1 expression in transitional cell carcinoma of the bladder: correlation with $\mathrm{p} 53$, waf1, $\mathrm{pRb}$ and Ki-67. Brit J Cancer 2001; 84: 270-275.

67. Valmanya Liena FR, Rodriguez L, Lloreta Trull J et al. Immunohitochemical expression of p53, p21, p16 and cyclin D1 in superfitial bladder cancer. A tissue microarray study. Actas Urol Esp 2006; 30: 754-762.

68. Yin Hui, Anthony SY, Leong Y. Histologic grading of noninvasive papillary urothelial tumors. Validation of the 1998 WHO/ISUP System by Immunophenotyping and Follow-up. Am J Clin Pathol 2004; 121: 679-687.

69. Yin, Hui, He, Qun, Li Ting, Anthony SY. Cytokeratin 20 and Ki-67 to distinguish carcinoma in situ from flat non-neoplastic urothelium. Appl Immunochem Mol Morphol 2006; 14: 260-265.

Received November 3, 2011. Accepted January 23, 2013. 